\title{
A MILLION TIMES SAVED
}

\section{M. Barbosa ${ }^{1}$}

It was an ordinary day in July. I was driving to work in San Diego, California. I woke up that day feeling very sick. A type of feeling that made my whole body hurt, even my heart. My sickness was psychological; I was suffering from depression. My life didn't have any meaning anymore. That day, the forecast was going to be a scorcher, around $105^{\circ} \mathrm{F}$. Suddenly, as I was leaving my house, a strong feeling came to my mind. I began to think about how to end my pain. I was driving and thinking about the fastest way to do it. Unexpectedly, I heard a voice inside of me say, "Don't do it, think about your girls." I was in shock. I thought I was hallucinating, but deep in my heart I knew it was true.

I continued driving on Santa Fe Road feeling ill and sad. I asked God to forgive me for my thoughts. When I got to work, I had to fake that I was fine. In the classroom, the kids knew something was wrong. They said, "Miss Kate, are you okay?" I told them, "Yes I'm fine." But the truth was that I was a very sad woman. I was devastated and my soul couldn't find peace or serenity. The hours passed so slowly, and as I watched the clock, I felt like I was standing still in time. Finally, it was time for lunch. Everybody ran to the cafeteria and teacher's lounge to eat. It was an ordinary day for everybody but me.

As everyone was leaving, you could hear people laughing and showing the undeniable excitement and happiness of going home. Quite the opposite, I debated on what to do because I didn't want to go home yet. As I said goodbye, I thought of going to a secret place of mine. I called this "The Secret Place" because it was a quiet road filled with lush and beautiful trees and wild animals like quails, birds, and coyotes passing by. I rushed out of the big school door, and I got in the car. Once in the car, all I wanted to do was cry. I cried all the way to the secret place, and I remember that I kept reciting a prayer that a very good friend taught me. This special prayer was like a balm to my desolated soul. The prayer was "Dear Jesus, you that loves me so much, look at me in this affliction and then do what your sensitive heart tells you. I do not want to worry; I leave everything in your hands. You, so kind and compassionate, you already know what to do for me."

\footnotetext{
${ }^{1}$ C. M. Barbosa is a Colombo-American author and educator. Her work includes fictional narratives and life stories on reflective moments in a person's life.
} 
I kept repeating this prayer in my desperation to alleviate my pain. I didn't know how to pray, so this was the closest thing to a prayer that I knew. The reality is that God was beside me, and I didn't even know it.

On repeated occasions, God had tried to let me know that I was not alone, but I was blind. My whole life I learned that God was in heaven looking at us from up above. I thought that God was very far away, and I cried out to God but with the doubt that he was unable to hear me. I reached the secret place sobbing with my eyes filled with tears and swollen from so much suffering. I looked at the sky and said, "Lord where are you; I need you." I waited but nothing happened. Then, I imagined that God appeared to me in the clouds. I looked for some sort of supernatural message to be written in the sky. As the sunset became more reddish, it was showing me that it was late and that I needed to head home to my family. Deep in my heart I just wanted to be there waiting for an answer.

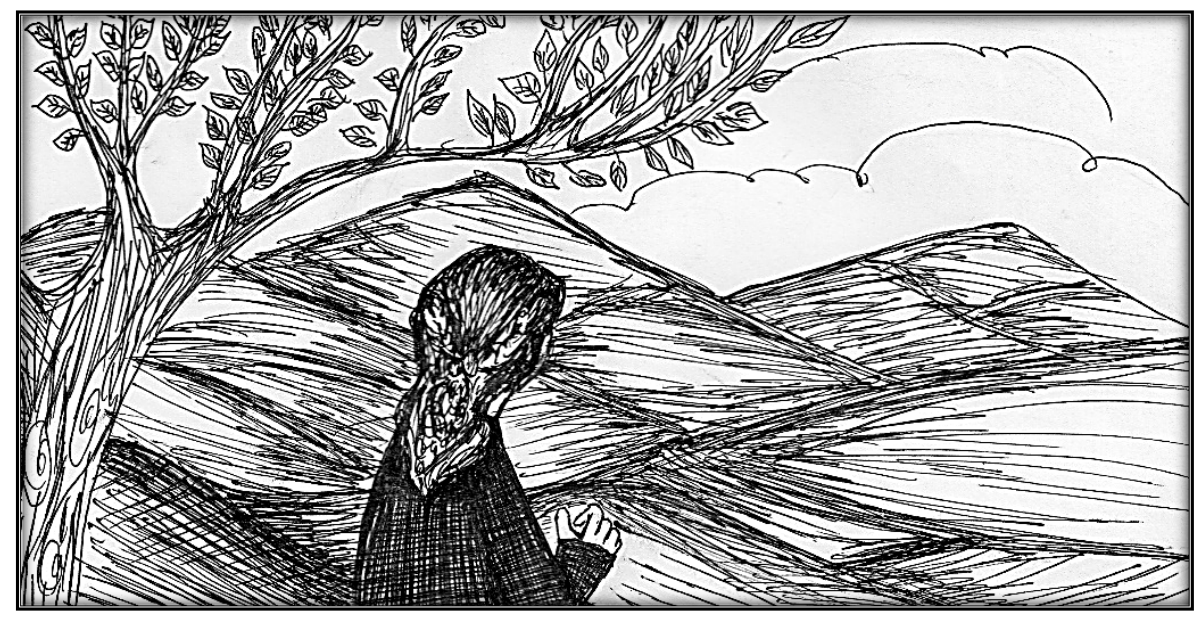

Many days, months, and even years passed since that day, and my heart was completely numb by so much suffering. I decided to move back to my home country, Romania. I searched for an answer; I went from church to church but to no avail. My sister asked me to go with her, and I accepted. Once, there I thought this was just another church. I felt confused when they said that God was going to talk to the people there. One part of me wanted to believe this was true, but the other part was very skeptical. The service ended, and it was time to find out the truth. I sat on the bench wondering what kind of trap I had walked into. Had my sister told these people my secrets? And then the Lord spoke to me. And what He said filled the desert of my heart with sweet consoling words. I was left speechless, astonished, and comforted. God had spoken to my heart. 
I went home and all I kept thinking about was the words that comforted and assured me that God was with me at all times. He was the one who had spoken to me that day I was driving and wished to take my own life. I can say with certainty that God has saved my life not one or two times, but a million times. He had saved my life from death itself. The Lord has healed my soul. Today, I am a determined woman, with joy in my heart, full of desire to live and please God, my daughters, and my family. The depression couldn't take me away from this world without experiencing the opportunity to get to know God and discover the real meaning of our existence on Earth. 